\title{
Anarhia salvează... democrația? Despre regula autoimpusă
}

Motto: Soon to fill our lungs the hot winds of death The gods are laughing, so take your last breath Fight fire with fire

Ending is near Fight fire with fire Bursting with fear

Metallica, Fight Fire with Fire, „Ride the Lightning” (1984)

Rezumat: Articolul analizează elementele folositoare din teoria (clasică a) anarhismului, adică ideea că o societate bine organizată impune fiecărui membru să înțeleagă și să respecte un corp comun de reguli pe care să le accepte de bunăvoie, în loc să stea să aștepte ca Statul să impună propriile reguli indivizilor. Făcând o paralelă între mișcările civice din România anului 1990 și recenta mișcare „Clack Lives Matter” din Statele Unite ale Americii, articolul pune în discuție posibilitatea de a înnoi o parte dintre regulile existente pe baza consultării populare cu păstrarea principiului statului de drept și a preeminenței legii.

Cuvinte-cheie: reguli, anarhie, democrație

\section{Does anarchy save... democracy? On the self-imposed rule}

Abstract: The paper analyses the good elements of (classical) anarchistic movement, i.e. the idea that a well-organized society requires each individual to understand and obey a common set of self-accepted rules rather than wait for the State to impose the rules unto each individual. By making a parallel between the 1990 civic movements in Romania and the current Black Lives Matter' movement in the United States, the paper explores the possibility of renewing the particular rules based on popular demands while keeping untouched the idea of 'rule of law' as a key principle in building a functional society.

Keywords: rules, anarchy, democracy

În 14 iunie 1990, președintele României adresa „minerilor”1 un apel care se va dovedi extrem de convingător: „Grupuri organizate de elemente incitate, multe din ele drogate, înarmate cu diverse elemente contondente, cu bare, cu lanțuri, cu pietre, cu cărămizi, cu țigle, au atacat cordoanele de polițiști, înarmați cu sticle incendiare, au dat foc la autobuze, la mașini și, apoi, grupuri, s-au îndreptat spre clădirea poliţiei pe care au incendiat-o, spre clădirea Ministerului de interne. Vă rugăm să faceți totul pentru a elimina excesele, pentru a elimina actele sângeroase, și dumneavoastră să asigurați paza necesară împotriva tuturor elementelor extremiste care și-ar mai face apariția în această zonă"2. În 15 iunie 1990, grupurile de mineri au sosit în Capitală și au „făcut ordine” în acea zonă „fără legi” care era Piața Universității. Președintele Iliescu le-a mulțumit în celebrul discurs: „Vă mulțumesc pentru tot ceea ce ați făcut în aceste zile, în general pentru toată atitudinea dumneavoastră de înaltă conștiință civică. Deci, vă mulțumesc încă o dată tuturor pentru ceea ce ați demonstrat și în aceste zile: că sunteți o forță puternică, cu o înaltă disciplina civică, muncitorească, oameni de nădejde și la bine, dar mai ales la greu. Și de asta dată ați demonstrat cât de importantă este solidaritatea muncitorească. Cu un sentiment deosebit de

\footnotetext{
${ }^{1}$ Pentru o punere în context extrem de interesantă a acelor evenimente, a se vedea A. Cornea, Puterea totală, disponibil la adresa https://psnews.ro/puterea-totala-406967/.

2 A se vedea https://www.b1.ro/stiri/politica/inregistrarea-cu-discursul-sustinut-de-ion-iliescu-pe-14-iunie-1990dovedeste-ca-acesta-ar-fi-chemat-minerii-la-bucuresti-liderul-asociatiei-21-decembrie-1989-mineriada-din-iunie1990-a-fost-o-operatiune-militara-video-120692.html
} 
conștiință civică, patriotică ați simțit momentul dificil și cu o dăruire exemplară v-aţi arătat gata să fiți solidari cu puterea nouă. Exemplul dumneavoastră a fost plin de îmbărbătare pentru toți cei de bine, care doresc progresul societății românești. Vreau să vă mulțumesc deci pentru acest act de înaltă solidaritate pe care 1-ați demonstrat în aceste zile"3.

În 15 iunie 2020, Președintele Statelor Unite ale Americii susține un discurs ${ }^{4}$ (în cadrul unei conferințe de presă la Casa Albă) în care susține că o zonă a orașului Seattle a fost ocupată de o grupare de extremă stânga. "These people have taken over a vast part, a major part, a very good part of a place called Seattle", a menționat Președintele Trump, precizând că "These are violent people that are dealing violently and I think that what I'd like to see before we do something, I'd like to see the press get in there and cover it". Ca răspuns la această amenințare, care riscă să se extindă ("The problem with what happened in Seattle is it spreads. and all of the sudden they'll say, 'Let's do some other city. And let's do another one.' And we're not going to let it happen.'), liderul american a propus o soluție de ,pacificare” prin intervenția armatei ${ }^{5}$. În paralel, am văzut filmări cu ,zona liberă” în care se realizează un ,control” la intrare și în care sediul secției de poliție a fost „redenumit” tot ca sediu de poliție, dar al ,poporului”, pentru a arăta că protestatarii doresc reformarea serviciului de poliție actual (ca în orice oraș din Statele Unite ale Americii, poliția este un serviciu al administrației publice locale, similar poliției locale de la noi). Altfel spus, ,,anarhiștii” nu neagă orice nevoie de ordine, ci doar neagă îndrituirea unei anumite autorități de a fi organul de asigurare a ordini. Se neagă practic atribuirea monopolului „,violenței” etatice.

\section{Anarhismul nu este anomie}

Într-un fragment destul de ambiguu din Politica $\mathrm{sa}^{6}$, Aristotel povestește situația în care cretanii renunța la oficiul cosmilor (aleși pe viață) drept o acosmie (,desființarea instituţiei cosmilor") urmată de o perioadă de anarhie ${ }^{7}$. Trebuie însă să nu uităm că Aristotel nu este cel mai neutru analist politic. El critică dur democrația și ia fățiș partea aristocrației ca formă superioară de organizare politică. De fapt, el scria într-un context în care democraţia ateniană își epuizase resursele, iar aristocrația macedoneană cucerea lumea cunoscută ${ }^{8}$. Așadar, îl putem considera pe Aristotel un adept al statului puternic centralizat. Cum însă gândirea aristotelică a stat la baza întregii filosofii medievale occidentale, nu este greu de înțeles de ce anarhia ajunge să fie asociată celei mai grave forme de „eșuare a statului”. În zilele noastre, Somalia și Siria, dar și Albania la sfârșitul anilor '90 sunt oferite ca exemple de anarhii.

În conștiința populară a teoriei politice, anarhia a ajuns să fie asociată cu lipsa oricărei reguli: fiecare face ce-l taie capul. Privită în acest fel, este evident că anarhia este un alt nume dat haosului (social). Dar analizând mai departe exemplele concrete de așa-zisă anarhie, observăm că toate păstrează o anumită formă de organizare a colectivităţii. În Somalia finalului de secol XX, fiecare regiune și-a definit o organizare proprie și a apelat la un anumit set de reguli. În Albania

\footnotetext{
${ }^{3}$ A se vedea https://evz.ro/discursul-de-neuitat-pe-care-ion-iliescu-l-a-tinut-minerilor-pe-15-iunie-1990-video.html

${ }^{4}$ Pentru înregistrarea discursului, a se vedea https://www.c-span.org/video/?c4887060/user-clip-trump-seattle-protest

${ }^{5}$ A se vedea https://www.nwpb.org/2020/06/15/president-trump-ramps-up-criticism-of-jay-inslee-and-jenny-durkanover-seattle-protest-zone/

${ }^{6}$ A se vedea Aristotel, Politica, editura Univers Enciclopedic Gold, București, 2015, p. 119-121, 1272b.

7 Pentru o interesantă analiză a acestui pasaj aristotelic, a se vedea A. Laffon, The meaning of acosmia in Aristotle, Politics II, 1272b1-16, în „Síntesis. Revista de Filosofía” vol. I, nr. 1/2018, p. 3-22. Adde L.-A. de Saint-Just, Théorie politique, textes établis et commentes par Alain Liénart, Seuil, Paris, 1976, p. 154: „si l'anarchie nait de la confusion des pouvoirs, là où il n'y aura point de pouvoirs il n'y aura point d'anarchie". Chiar și poliarhia a fost văzută uneori ca o formă de anarhie. A se vedea Eusebiu din Cezareea, Tricennalia, III.5, în V. Nistor (coord.), Magistrați și eunuci. Putere formală și putere reală în antichitatea târzie, editura Paideia, București, 2016, p. 178: „bunăoară poliarhia, rezultând din egalitatea în drepturi capătă până la urmă chipul anarhiei și al discordiei civice”.

${ }^{8}$ Există chiar opinia că Aristotel ar fi acționat ca un ,spion” al regelui macedonean Filip în Atena. A se vedea A.-H. Chroust, Aristotle: New Light on His Life and On Some of His Lost Works, vol. 1, Some novel interpretations of the man and his life, Routledge \& Keegan Paul, Londra, 1973, p. 197-218.
} 
aceleiași perioade, bandele de traficanți au preluat aplicarea legii. În Piața Universității din 1990, accesul la „,balcon” se făcea după anumite reguli. În zona liberă din Seattle, accesul se face după un control prealabil, iar încălcarea regulilor este sancționată. De fapt, fotografia care mi se pare mie emblematică este cea în care doar denumirea secției de poliție a fost obturată de graffitti, dar ideea de ,poliție”, adică de veghere la aplicarea regulilor a rămas.

Dacă ne raportăm la principalul filon al teoriei anarhiste din a doua jumătate a secolului al XIX-lea, vom observa că niciunul dintre autorii ,clasici” nu a avut în vedere eliminarea sistemului de reguli și de impunere a acestora ${ }^{9}$. Nici măcar Proudhon, cel care a devenit faimos pentru celebra declarare a proprietății private drept furt, nu intenționa să înlăture orice ierarhie. Principala lor nemulțumire era îndreptată împotriva statelor totalitate din epocă. Ca o alternativă, anarhiștii sugerau ca fiecare individ să fie prezumat ca având suficient discernământ încât să acționeze în sensul cooperării cu semenii săi. Prin urmare, statul ar putea să prezume că fiecare om se va comporta civilizat și să renunțe să-și trateze cetățenii ca prezumtivi infractori. Anarhia „clasică” își propunea să extindă sfera libertății individuale.

De aceea, în secolul XX (şi chiar și în zilele noastre) anarhia se transformă în libertarianism, ceea ce oferă o descriere mai exactă a ideilor din spatele curentului. Într-o societate în care părea că democrația constituțională s-a impus implacabil ${ }^{10}$, singura întrebare rămasă era cât de multă libertate trebuie permisă individului în raport cu societatea. Altfel spus, cât de mult depinde coeziunea socială de nevoia unor reguli care să oblige cetățeanul să coopereze. Aici libertarienii par să susțină că omul, ca ființă eminamente socială, va coopera cu ceilalți semeni chiar și dacă legea nu i-o cere în mod expres. Cei mai radicali susțin chiar că legea nu ar trebui să impune vreo formă de cooperare forțată, în timp ce moderații acceptă că anumite proiecte strategice (de exemplu, infrastructura) necesită în continuare o cooperare ,ajutată” de stat, pentru că viziunea strategică este ineficient să se bazeze pe o cooperare individuală ${ }^{11}$.

În toate cazurile, însă, acești teoreticieni pleacă de la premisa că există reguli și că fiecare individ trebuie să le respecte. În definitiv, fiecare are libertatea să facă tot ceea ce vrea, doar în măsura în care astfel nu îi afectează pe niciunul dintre ceilalți indivizi. Îndemnul paulinic de a-i respecta pe ceilalți12 sintetizează tocmai această regulă ${ }^{13}$ (sic!) de bun simț. Pentru a pretinde celorlalți să-mi recunoască libertatea, trebuie și eu să le-o recunosc lor. Or, în cadrul unei societăți, libertatea celorlalți tinde să limiteze sfera libertății mele. O societate bine organizată va face în așa fel încât granița dintre libertățile fiecărui individ să fie cât mai aproape de medie, pentru a asigura fiecăruia gradul optim de fericire.

În acest punct, apare ideea pe care criticii o asociază cel mai adesea cu anarhismul: o astfel de libertate generală reprezintă o, ,rețetă” sigură pentru dezastru, pentru că anarhia pe care o generează va duce la dezagregarea societății. La această critică, anarhiștii țin să facă o precizare: ei nu pledează pentru anarhie în sensul anomiei (adică a lipsei - sau nerespectării - regulilor), ci doar pentru o regulă comună tuturor și pe care orice individ cu discernământ o va putea aplica și singur (din convingere). Căci numai cel care nu (mai) are nimic de pierdut va accepta senin să nu respecte nicio regulă.

\footnotetext{
${ }^{9}$ Pentru o bună sinteză, a se vedea G. Crowder, Anarhismul clasic. Gândirea politică a lui Godwin, Proudhon, Bakunin şi Kropotkin, editura Antet, București, 1997.

${ }^{10}$ Optimismul afișat de Francis Fukuyama în Sfârșitul istoriei și ultimul om, pare astăzi o simplă utopie milenaristă.

${ }^{11}$ Imaginați-vă proiectul unei autostrăzi. Dacă ne așteptăm ca autostrada să se (proiecteze și) construiască prin contribuția benevolă a posibililor beneficiari, este posibil ca proiectul să nu se materializeze niciodată sau, mult mai probabil, să fie ineficient. De exemplu, este posibil ca anumiți proprietari de terenuri să solicite ca traseul autostrăzii să treacă pe terenurile lor sau alții să refuze traversarea propriei proprietăți.

${ }^{12}$ Sfântul Pavel, Epistola către Romani, 12.18: „Dacă se poate, pe cât stă în puterea voastră, trăiți în bună pace cu toți oamenii".

${ }^{13}$ Tot Sfântul Pavel spune că „De aceea este nevoie să vă supuneți, nu numai pentru mânie, ci și pentru conștiință” (Romani, 13.5).
} 


\section{Anarhismul nu este antietatic}

Și acum ajungem la cealaltă critică adusă anarhismului: disoluția statului. Dacă acceptăm că anarhiștii nu-și propun aducerea haosului pe pământ și dispariția societății, atunci în mod clar ei luptă împotriva statului, ceea ce este (cel puțin) la fel de rău. O să încerc să văd dacă într-adevăr anarhismul își propună să distrugă statul.

Trăsătura comună a anarhiștilor (mai vechi sau mai noi) este aceea că nu cred în eficiența organizării statale. Altfel spus, ei consideră că statul a crescut astăzi atât de mult încât tinde să se prăbușească sub propria sa greutate. Anarhismul modern nu pledează numai pentru autodeterminarea individului, ci pentru un sistem poliarhic în care puterea să nu fie concentrată într-un singur punct (sau la un singur grup). Plecând de la premisa că puterea corupe, anarhiștii își doresc să dilueze puterea în așa fel încât ea să nu poată fỉ folosită în mod facil împotriva indivizilor. Puterea (publică) ar trebui să servească indivizilor, iar nu sieși. Puterea de dragul (menținerii) puterii este ceea ce neagă anarhiștii. Dacă în secolul al XIX-lea acest deziderat părea să fie identic cu cel de distrugere a statului (să ne amintim că Proudhon lovea la baza organizări statului burghez), secolul următor a arătat o nuanțare evidentă. Nu se mai vorbește despre distrugerea statului, ci de eliminarea din sfera etatică a acelor atribuții (servicii) care pot fi realizate mult mai eficient în regim de cooperare privată.

Mișcarea nu este una nouă. Să ne amintim că pirații secolelor XVI-XVIII preferau să se plaseze în afara controlului etatic pentru că astfel puteau să opereze mult mai suplu. Atunci când regina Elisabeta I a Angliei a observat faptul că pirații erau mult mai eficienți contra spaniolilor decât flota sa de război, a ales să-și (re)organizeze o parte a flotei după tiparul piraților. Sir Francis Drake a reuşit astfel să dezvolte ceea ce astăzi am numi o luptă de gherilă care a permis după un secol ca supremația pe mare să treacă de la Spania către Anglia. În secolul XX, „haitele” de submarine germane acționau după principii similare și aproape că au reușit (într-o primă fază) să anihileze puterea maritimă britanică. Nimeni nu poate afirma însă că piraţii (privaţi sau „sponsorizați” de stat) nu acționau după un set de reguli. Celebra serie Disney Pirații din Caraibe face deseori trimitere la un anumit cod de conduită respectat de către toți pirații. Iar pe corabie (unitatea „de bază” a piraților), era evident că exista o ordine clară. Celebra imagine platoniciană a cetății văzută ca o corabie pe care timonierul trebuie să acționeze fără a-i fi puse la îndoială deciziile își vădește astfel perenitatea. Chiar și pirații moderni acționează după anumite reguli, iar cuvântul care descrie activitatea piraților informatici este, uneori, un termen argotic pentru reguli: „Rulez”...

Dar să revenim la mișcările moderne care au fost acuzate de anarhism. Din seria care a început cu Occupy, a continuat cu \#rezist și a ajuns astăzi să fie asociată cu Black Lives Matter, putem totuşi să vedem că nu existența statului este pusă la îndoială, ci doar anumite acțiuni ale statului care pun în pericol individul și chiar colectivitatea ca atare. Este mai degrabă vorba despre mișcări în care o parte a populației nu se (mai) regăsește în acțiunile celor care conduc statul. Uneori (precum în cazul mișcării \#rezist), protestul este îndreptat tocmai împotriva încercării guvernanților de a deturna Statul pentru propriile scopuri individuale. Valoarea pentru care acei ,anarhiști” care ocupă piețele publice luptă este tocmai „domnia legii”, „statul de drept”, altfel spus - respectarea regulilor. Aceste mișcări au ca element comun critica funcționării statului, nu existența acestuia ${ }^{14}$. Ba chiar își propun (re)instaurarea statului de drept.

La o privire mai atentă, între Piața Universității din $1990^{15}$ și Piața Victoriei din $2017 \mathrm{nu}$ există o diferență de esență. În ambele cazuri, o parte a populației nu era mulțumită de modul în

\footnotetext{
${ }^{14} \mathrm{Nu}$ înseamnă că toate mișcările anarhiste apără aceste valori, dar cele pe car ele analizez aici sigur o fac.

${ }_{15}$ Pentru o analiză extrem de interesantă, a se vedea A. Gussi, 30 de ani de (auto) intoxicare. Episodul 3. Violențele din 13-15 iunie sau diversiunea ca model de succes $\hat{\imath}$ postcomunism, disponibil la adresa http://www.contributors.ro/politica-doctrine/30-de-ani-de-auto-intoxicare-episodul-3-violen\%c8\%9bele-din-13-15iunie-sau-diversiunea-ca-model-de-succes-in-postcomunism/.
} 
care „cârmaciul” conducea „corabia”. Erau observatorii care, din „cuibul de rândunică” din vârful catargului puteau vedea stâncile către care se îndrepta corabia. Iată cum valorile anarhismului (creșterea implicării individului în conformarea voluntară, reducerea rolului statului în viața individului, critica deciziilor puterii) încep astăzi să sune extrem de apropiate de cele ale democrației liberale de azi. Poate că tocmai aceste „mișcări anarhiste” reprezintă normalitatea unei democrații constructive. Faptul că ele sunt demonizate de către Stat nu arată decât că Statul nu este încă pregătit să renunțe la putere(a absolută).

Unele comentarii la textele anterioare despre primatul regulilor au sugerat că apărarea regulii reprezintă o poziție conservatoare (ca să nu spunem reacționară) prin care se tinde la menţinerea status quo-ului în general și a actualei conduceri politice în particular. Cred că regulile sunt mai mult decât simple instrumente ale impunerii unei ideologii sau ale opresiunii politice și ele reprezintă fundamentul organizării omului ca ființă socială. Regulile particulare nu sunt imuabile, ele se schimbă o dată cu evoluția societății, dar ideea de regulă și de respectare a regulii rămâne o constantă a oricărei societăți (funcționale), indiferent de modul său de organizare. În definitiv, regulile (nepotrivite) nu pot fi înlocuite decât cu alte reguli (mai bune).

Materialul a fost publicat în revista online a Facultății de Drept, $\underline{\text { AUBD - Forum Juridic nr. }}$ $\underline{2 / 2020 .}$ 